Int. J. Morphol.,

23(4):323-328, 2005.

\title{
Ultrastructural Aspects of Spermatids in Isogenic Black Mouse C57BL6J
}

\author{
Aspectos Ultraestructurales de las Espermátidas en el Ratón Negro Isogénico C57BL6 \\ Márcia Regina Fernandes Boaro Martins \& José Ricardo de Carvalho Pinto e Silva
}

\begin{abstract}
MARTINS, M. R. F. B. \& SILVA, P. J. R. C. Ultrastructural aspects of spermatids in isogenic black mouse C57BL6J. Int. J. Morphol., 23(4):323-328, 2005.

SUMMARY: The objective of this study was to describe some changes in spermatids differentiating events during spermiogenesis, leading to spermatozoa final formation. The animals were sacrificed with ethylic acid inhalation and, then, testis fragments were collected, fixed in Karnovsky and post-fixed in osmium tetroxide. After dehydration, the sections were stained with uranyl acetate $2 \%$. It was observed in early spermatids at Golgi phase, formation of acrosomal granule contained in the acrosomal vesicle, spheroidal nucleus with rugous reticulum around it, and Golgi apparatus made up of lamellae and vesicular structures. At cephalic hood phase, the granule suffers flattening and the marginal fossa is formed. In both phases, it was possible to observe the presence of multivesicular body. At acrosomal phase, the acrosomal system is set up, and several enzymes of endoplasmatic reticulum as well chromatoid body are observed in the cytoplasm. At the last phase, that is, maturation, the nucleus becomes more elongated, the endoplasmatic reticulum regresses, the Golgi apparatus approaches to the flagellum and mitochondrias align next to it.
\end{abstract}

KEY WORDS: Spermiogenesis; Spermatids; Mice.

\section{INTRODUCTION}

In mammalian spermiogenesis, marking nucleocytoplasmatic changes and evolutionary alterations of the cytoplasmatic organules involved in the formation of cephalic cap, acrosome, flagellum, round spermatids, elongated spermatids and spermatozoa, are ultra-structurally characterized.

It has been shown by light and electron microscopy, that the Golgi apparatus in early spermatids is the main organelle involved in acrosome formation (Burgos et al., 1970; Mollenhauer et al., 1976; Burgos \& Gutiérrez, 1986). One of the most important features of the Golgi apparatus is that its product and wrapping membrane are initially stored in the acrosome, before being immediately secreted into the extra-cellular mean (Burgos \& Gutiérrez).

The acrosome development during spermiogenesis is well documented by Leblond \& Clermont, (1952); Bedford \& Nicander, (1971); Plöen, (1971); Phillips, (1972); Dym, (1977), Maxwell, (1982).

Studies performed with enzymatic activities and tritiated sugars in rat spermatid report that the Golgi apparatus in early spermatids produces, besides the pro-acrosomal granule, multivesicular body, which associates to the chromatoid body (Tang et al., 1982).

The chromatoid body is transitorily associated with the Golgi apparatus in round spermatids (Fawcett et al., 1970; Susi \& Clermont, 1970; Parvinen \& Jokelainen, 1974; Thorne-Tjomsland et al., 1988). Its structures is primarily made up with filamentous granule material and is related to carbohydrate-rich vesicles (Susi \& Clermont; ThorneTjomsland et al.). On the other hand, based on histochemical reactions, Sud (1961); Fawcett et al., concluded that it is composed of basic proteins and ribonucleic acid. According to Fawcett et al., there is no evidence to support the nuclear origin of chromatoid body, however, Comings \& Okada (1972) postulates a probable nuclear origin of this structure.

Little attention has been given to another cellular component, the endoplasmatic reticulum, which also suffers structural changes during spermiogenesis. However, some studies on its development and evolution have been done during human spermiogenesis (Nistal et al., 1980); in rodents (Clermont \& Rambourg, 1978), and in bats (Orsi et al., 1992). 


\section{MATERIAL AND METHOD}

Five 50 to 60-day old, isogenic black mices C57BL6J were sacrificed with ethylic ether inhalation, and then had their testicles removed. For light microscopy analysis, one testis was fixed in Bouin and the sections stained with hematoxylin and eosin, while the other was fixed in Karnovsky's for 4 hours, post-fixed in osmium tetroxide $1 \%$ and in phosphate buffer for 2 hours, for electron microscopy. After dehydration, the testis were embedded in Araldite and the sections stained with uranyl acetate $2 \%$. The analysis was done by using transmission electron microscopy Philips EM 301, where cellular aspects were photographed.

\section{RESULTS}

During the spermiogenesis process of isogenic black mice, it was observed in early spermatids (round) at Golgi phase, some changes in the Golgi apparatus region, which contributes with carbohydrate-rich material to form 2 or 3

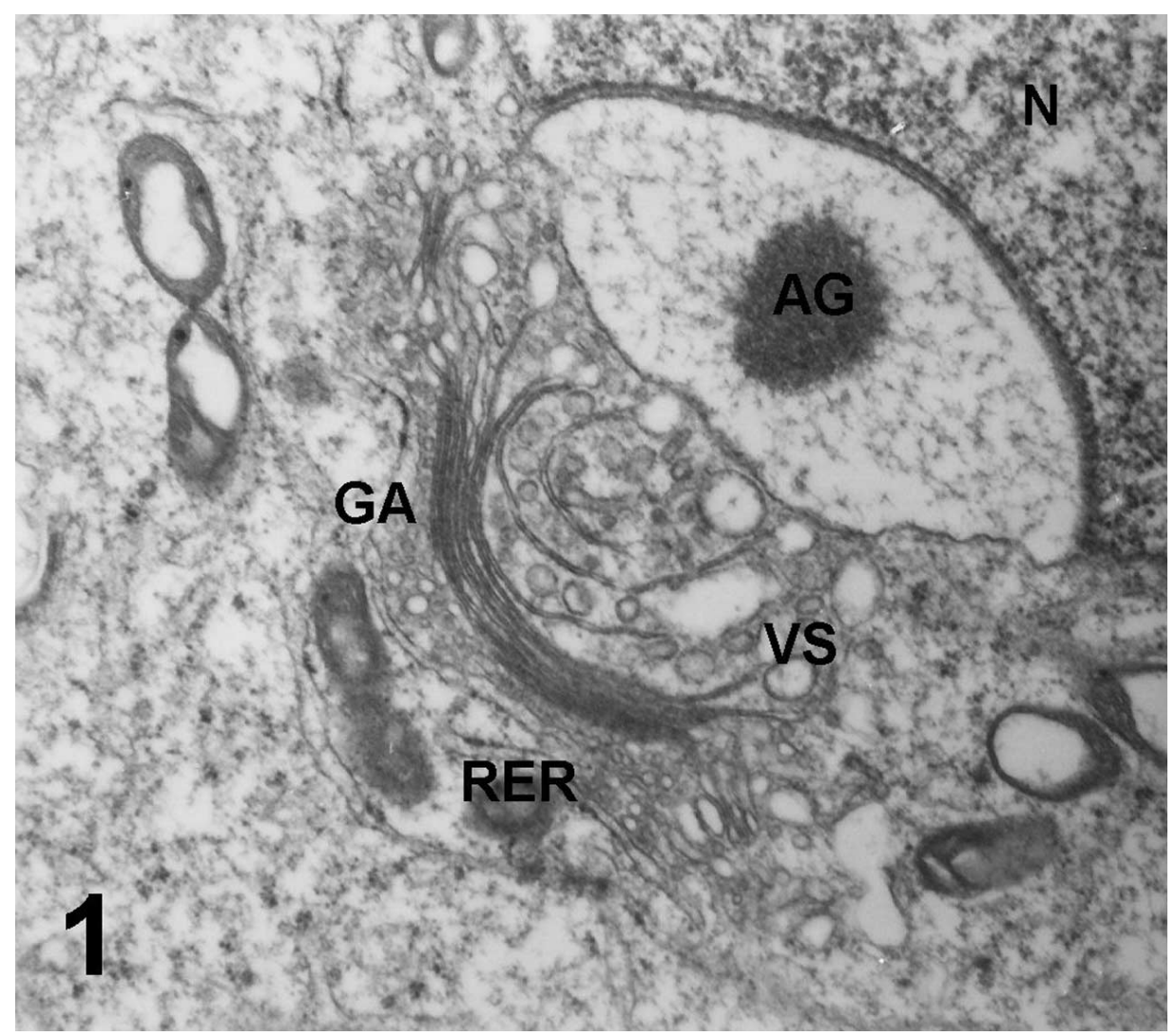

pro-acrosome granules that associate to form the acrosome granule contained in an acrosomal vesicle. In this phase, the cells presented spheroidal nucleus and rugous endoplasmatic reticulum, located preferentially around the nucleus. The Golgi apparatus showed to be made up of lamellae, saculations and vesicular structures, keeping relations of adjacence with the endoplasmatic reticulum, forming a discontinuous cover around it (Fig.1).

At cephalic cap phase, the acrosomal granule flattened on the nucleus, and the cephalic cap developed in the nucleus cranial pole. The nucleus portion adjacent to the acrosomal vesicle posterior margin suffered an alteration in its contour and formed the marginal fossa (Fig.2a), causing a light enlargement in the subacrosomal space (Fig.2b). In both phases, it was possible to observe the presence of multivesicular body, a thick structure delimited by a membrane full of small vesicles loosen in its interior (Fig. 3)

At acrosomal phase (Fig.4), one-third of the nucleus was covered by the cephalic cap and acrosomal granule. The combination of acrosome and acrosomal vesicle formed the acrosomal system, usually referred to as acrosome. At the beginning of this phase, the nucleus shape turned from spheric to ovoid, while in the cytoplasm, it was noticed large quantity of endoplasmatic reticulum vesicles and chromatoid body, which migrated slowly toward the cell caudal pole located oppositely to the acrosomal system. As these cells approached the following phase, the nucleus shape kept changing, becoming more and more elongated until maturation phase (Fig.5), where the endoplasmatic reticulum regressed, contributing actively, with its changes, to differentiate spermatids to spermatozoa. The Golgi apparatus turned to occupy a central site in the cytoplasm, near the flagellum, and the mitochondrias were aligned along the flagellum fibrous components.

Fig. 1. Spermatid at Golgi phase. Golgi apparatus (GA), acrosomal granule (AG), nucleus (N), rugous endoplasmatic reticulum (RER) and vesicular structures (VS) are observed. 

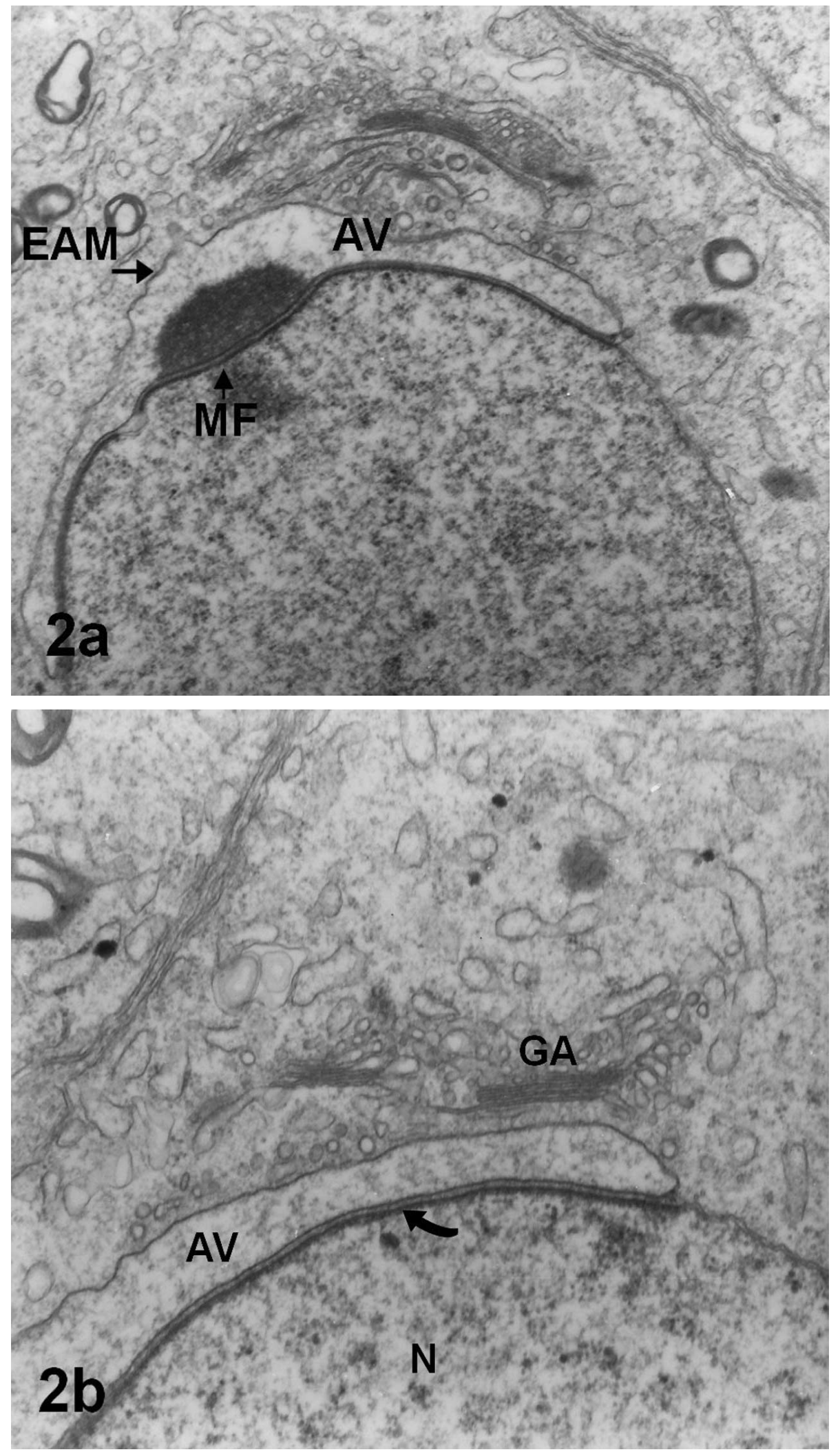

Fig. 2: Spermatid at cephalic cap phase; a) external acrosomal membrane (EAM), acrosomal vesicle (AV), marginal fossa (MF); b) Golgi apparatus (GA), acrosomal vesicle (AV), nucleus (N) and subacrosomal space (arrow).

\section{DISCUSSION}

The major stages of spermatids development, which characterizes spermiogenesis, were described by several authors in different mammalians, with the use of optical microscopy (Clermont, 1972). In rodents, including mouse albino (Leblond \& Clermont; Oakberg, 1956) and isogenic black mouse (Martins, 1993, 1999 and Martins et al., 2001), the different stages and phases of the spermatogenetic process were characterized.

During the cellular growth and secretion within the spermatids differentiating process in spermiogenesis, Burgos \& Gutiérrez, refer to Golgi apparatus as a dynamic cytoplasmatic structure.

As previously established by Jamieson \& Palade, 1977, Susi et al., 1971 and Mollenhauer et al. the proteins are synthesized in the rugous endoplasmatic reticulum, transported to Golgi apparatus, where they are transformed into glicoproteins and released for the acrosomal system development. In this process context, Mollenhauer et al., recognized, in guinea pig early spermatids, the existence of intermediate and condensed vesicles related with the rugous endoplasmatic reticulum and acrosome, respectively, being that the vesicles presented characteristics common to the plasmatic membrane. In our results, it could be observed in early spermatids (Golgi phase), vesicular structures next to Golgi apparatus, agreeing with Mollenhauer et al., who suggest 

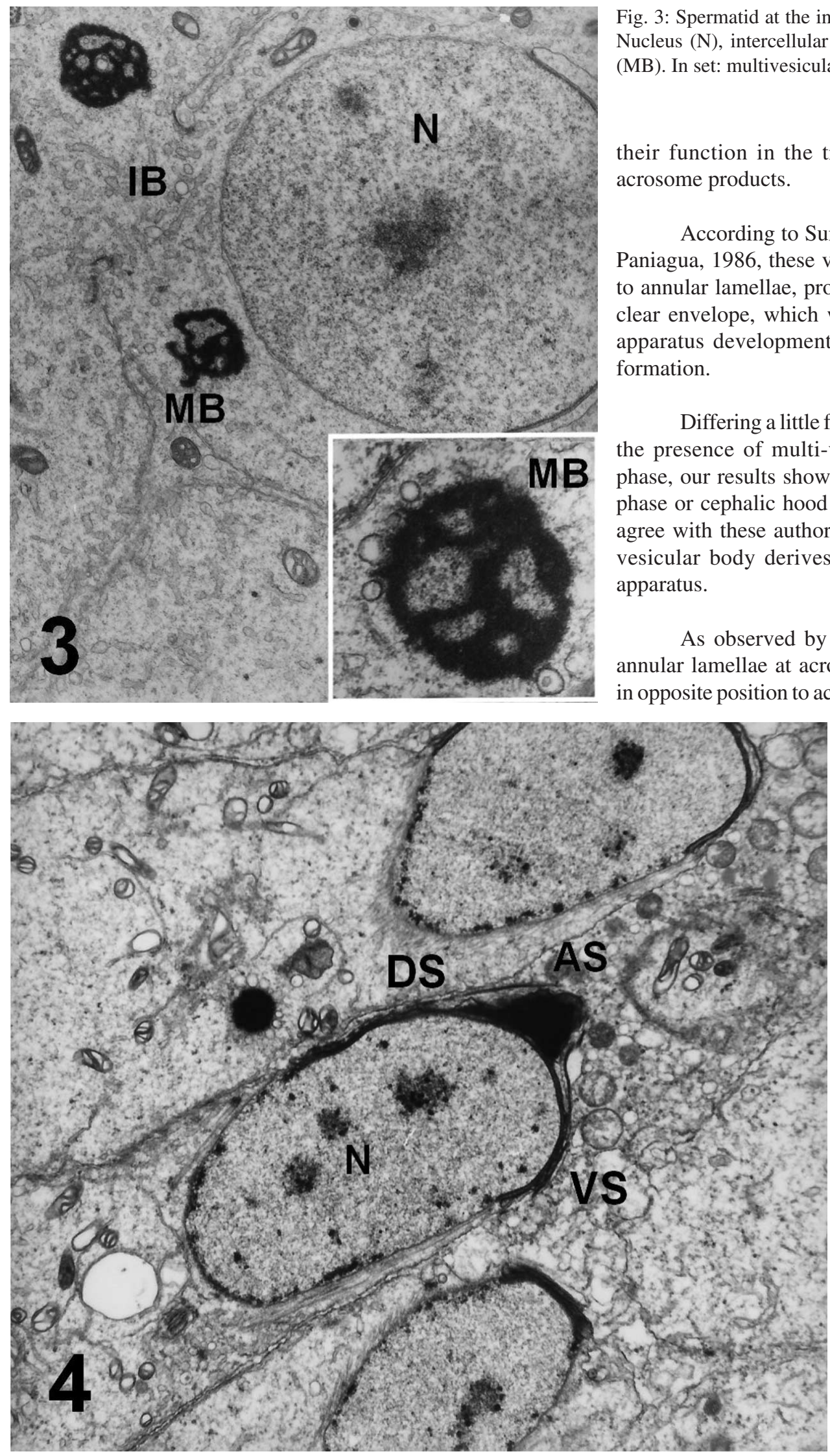

Fig. 3: Spermatid at the initial phase of the spermiogenesis. Nucleus (N), intercellular bridge (IB), multivesicular body (MB). In set: multivesicular body (MB).

their function in the transport of reticulum-Golgiacrosome products.

According to Sun et al., 1977; Nistal et al. and Paniagua, 1986, these vesicular structures correspond to annular lamellae, probably originated from the nuclear envelope, which would contribute to the Golgi apparatus development and, indirectly, to acrosome formation.

Differing a little from Tang et al., who highlights the presence of multi-vesicular body only at Golgi phase, our results show such structure either at Golgi phase or cephalic hood phase. On the other hand, we agree with these authors, who assume that the multivesicular body derives from elements of the Golgi apparatus.

As observed by Nistal et al., the presence of annular lamellae at acrosomal and maturation phases in opposite position to acrosome, was also characterized in isogenic black mouse in this study. Holstein \& Roosen-Runge, 1981; Paniagua et al., 1986 consider that the destine of the chromatoid body and annular lamellae is the spermatids neck region, which also contains ribonucleoprotein (Esponda, 1983; Czaker, 1985), suggesting that the chromatoid body and annular lamellae may be involved with the transport of these proteins to structures of the spermatids neck region.

Fig. 4: Spermatid in final stage of acrosomal phase. Nucleus $(\mathrm{N})$, acrosomal system (AS), acrosomal system stalks: dorsal stalk (DS) and ventral stalk (VS). 


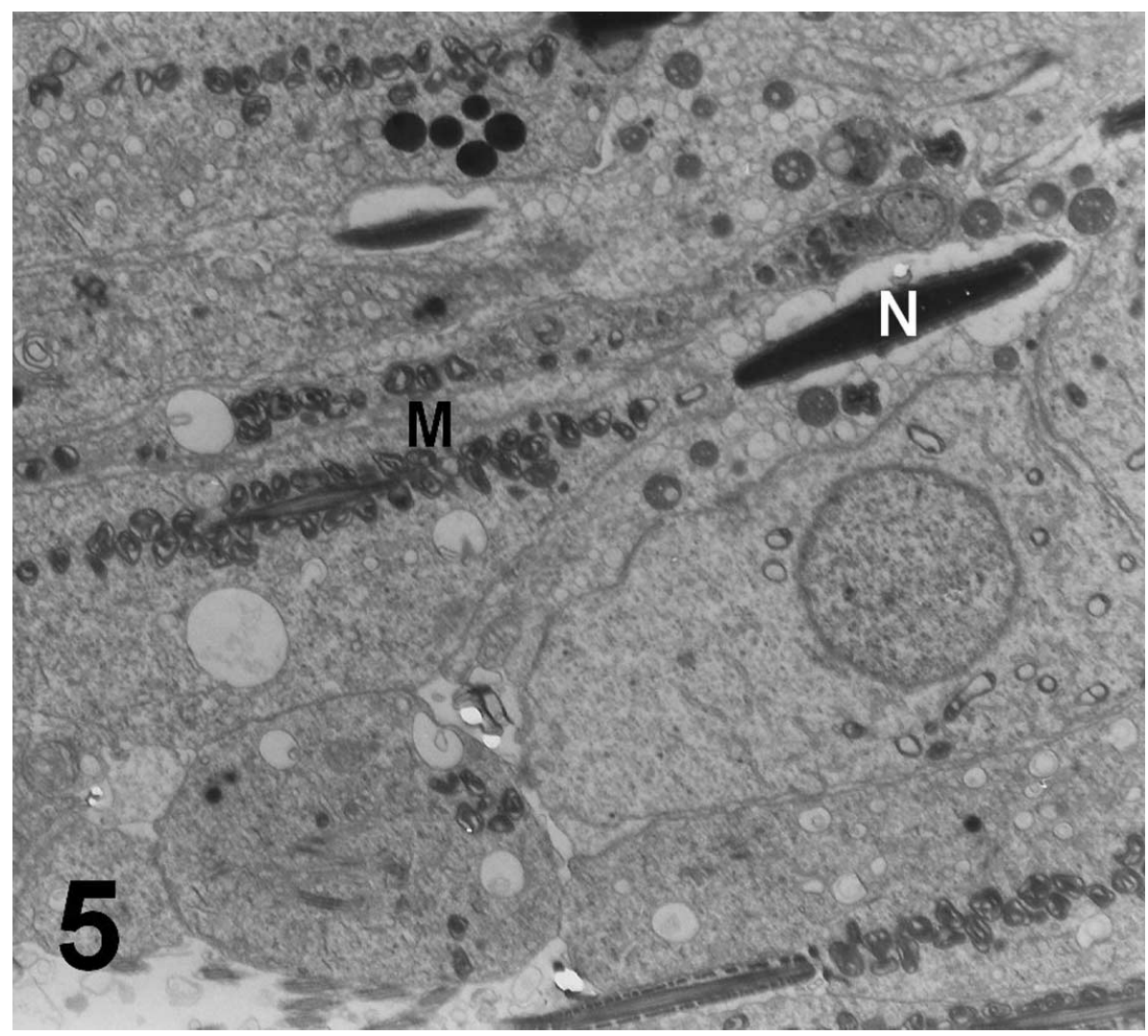

Fig. 5: Spermatid at maturation phase. Elongated nucleus $(\mathrm{N})$, mitochondrias $(\mathrm{M})$ aligned along the flagellum.

MARTINS, M. R. F. B. \& SILVA, P. J. R. C. Ultrastructural aspects of spermatids in isogenic black mouse C57BL6J Int. J. Morphol., 23(4):323-328, 2005.

RESUMEN: El objetivo del estudio, fue describir algunas alteraciones producidas en la espermiogénesis, en los eventos que diferencian a las espermátidas y que llevan a la formación final de los espermatozoides. Los ratones fueron sacrificados con inhalación de éter etílico y, enseguida, se recolectaron fragmentos de testículos, los que fueron fijados en Karnovsky y tetróxido de osmio. Después de la deshidratación, los cortes fueron teñidos con acetato de uranilo al $2 \%$. En espermátidas jóvenes en la fase de Golgi se observan: formación del gránulo acrosómico contenido en la vesícula acrosómica, núcleo esferoidal con retículo rugoso a su alrededor, y aparato de Golgi formado por lamelas y estructuras vesiculares. En la fase de capuz cefálico, el gránulo sufre achatamiento y se forma la fosa marginal. En estas dos fases fue posible observar la presencia del cuerpo multivesicular. En la fase acrosómica se establece el sistema acrosómico, distingiéndose en el citoplasma muchas vesículas de retículo endoplasmático y cuerpo cromatoide. En la última fase, la de maduración, el núcleo se torna más alargado, el retículo endoplasmático retrae, el aparato de Golgi se aproxima al flagelo y las mitocondrias se alinean a lo largo de él.

PALABRAS CLAVE: Espermiogénesis, Espermátidas; Ratones.

\section{REFERENCES}

Bedford, J. M. \& Nicander, L. Ultrastructural changes in the acrosome and spermmembranes during maturation of spermatozoa in the testis and apididymis of the rabbit and the monkey. J. Anat., 108:527-43, 1971.

Burgos, M. H. \& Gutiérrez, L. S. The Golgi complex of the early spermatid in guinea pig. Anat. Rec., 216:139-45, 1986.

Burgos, M. H; Vitale-Cañper, R. \& Aoki, A. Fine structure of testis and its functional significance. In: The testis. A. D. Johnson, W. R. Gomez. And N. L. Vandermark, eds. Academic, New York and London, 1:551-649, 1970.
Clermont, Y. Kinectis of spermatogenesis in mammals seminiferous epithelium cycle and spermatogonial renewal. Physiol. Rev., Bethesda, 52:198-236, 1972.

Clermont, Y. \& Rambourg, A. Evolution of the Endoplasmic Reticulum during rat spermiogenesis. Am. J. Anat., 151:191212, 1978 .

Comings, D.E. \& Okada, T. A. The chromatoid body in mouse spermatogenesis. Evidence that it may be formed by the extrusion of nucleolar components. J. Ultrastructure Research., 39:15-23, 1972. 
Czaker, R. Distinct argyrophilic cytoplasmic organelles reveled during mouse spermiogenesis. Afine structural and cytochemical study. Anat. Embryol,. 172:247-54, 1985.

Dym, M. The male reproductive system. In: Histology (eds. L. Weiss and R.O. Greep), 1977. pp 979-1038.

Esponda, P. The neck region of mouse spermatids. In: André S (ed) The sperm cell. Fertilizing power, surface properties, mortility, nucleus and acrosome. Evolutionary aspects. Nijhoff, The Hague, 399-402, 1983.

Fawcett, D.W.; EDDY, E. M. \& PHILLPS, D.M. Observations on the fine structure of the chromatoid body in mammalian spermatogenesis. Biol. Reprod., 2:129-53, 1970.

Holstein, A. F. \& Roosen-Runge, E. C. Atlas of human spermatogenesis. Grosse, Berlin, 1981.

Jamieson, J. D. \& Palade, G.E. Production of secretory proteins in animal cells. In: Internacional Cell Biology. B.R. Brinkley and R. Porter, eds. Rockefeller University Press, New York, 1977. pp. 308-17.

Leblond, C. P. \& Clermont, Y. Spermeiogenesis of rat, mouse, hamster and guinea pig as revealed by the "periodic acidfuchsin sulfurous acid" technique. Am. J. Anat., 90: 167-215, 1952.

Martins, M.R.F.B. Aspectos morfológicos da espermatogênese no camundongo (Mus musculus, L. Rodentia). O ciclo espermatogenético na variedade negra isogênica C57BL6J. Tese de Doutoramento apresentada ao Instituto de Biociências da Universidade Estadual Paulista-UNESP - Campus de Botucatu, 1993.

Martins, M. R. F. B. Histochemical and structural characteristics of the testes of isogenic black mice (Rodentia: Muridae). Braz. J. Morphol. Sci., 16(1): 5-9, 1999.

Martins, M. R. F. B. \& Silva, P. J. R. C. Ultrastructure of spermatogonia and primary spermatocytes of C57BL6J mice. Anat. Histol. Embryol., 30(3):129-92, 2001.

Maxwell, W. L. The acrosomal zonule. Tissue \& Cell, 14(2): 283-8, 1982.

Mollenhauer, H. H.; Hass, B. S. \& Morre, J. D. Membrane transformations in Golgi apparatus of rat spermatids. $J$. Microsc. Biol. Cell., 27:33-6, 1976.

Nistal, M.; Paniagua, R. \& Esponda, P. Development of the endoplasmic reticulum during human spermatogenesis. Acta anat., 108:238-49, 1986.

Oakberg, E. F. A description of spermiogenesis in mouse and its use in analysis of the cycle of the siminiferous epithelium and germ cell renewal. Am. J. Anat., 99:391-413, 1956.
Orsi , A. M.; Vicentini, C. A. \& Dias, S. M. Ultrastructural characteristics of the acrosomal development in vampire bat. (Desmodus rotundus, G., Microchiroptera). Zool. Jb. Anat., 122:35-42, 1992.

Paniagua, R.; Nistal, M.; Amat, P. \& Rodríguez, M.C. Ultrastructural observations on nucleoli and related structures during human spermatogenesis related structures during human spermiogenesis. Anat. Embryol., 174: 301-6, 1986.

Parvinen, M. \& Jokelainen, P.T. Rapide movements of the chromatoid body in living early spermatids of the rat. Biol. Reprod., 11:85-92, 1974.

Phillips, D. M. Substructure of the Mammalian acrosome. J. Ultrastructure Research., 38:591-604, 1972.

Plöen, L. A scheme of rabbit spermatogenesis based upon electron microscope observations. Z. Zellforsch. Mikrosk. Anat., 115:553-64, 1971.

Sud, B. Morphological and histochemical studies of the chromatoid body and related elements in spermatogenesis of the rat. Quart. J. Microscop. Sci., 102:495-505, 1961.

Sun, C.N.; Chew, E. C. \& White, H. J. Cytoplasmic annulate lamellae and intra nuclear membranes in human spermatids and sperm. Cell. Biol. Int. Rep., 1:345-51, 1977.

Susi, F. R. \& Clermont, Y. Fine structure modifications of the rat chromatoid body during spermiogenesis. Am. J. Anat., 129:177-92, 1970.

Susi, F. R.; Leblond, C. P. \& Clermont, Y. Changes in the Golgi apparatus during spermatogenesis in the rat. Am. J. Anat., 130:251-68, 1971.

Tang, X.M.; Lalli, M. F. \& Clermont, Y. A cytochemical study of the Golgi apparatus of the spermatd during spermiogenesis in the rat. Am. J. Anat., 163: 283-94, 1982.

Thorne-Tjomsland, G.; Clermont, Y. \& Hermo, L. Contribuition of the Golgi Apparatus components to the formation of the Acrosomic System and Chromatoid Body in Rat Spermatids. Anat. Rec., 590-8, 1988.

Correspondence to:

Prof. Dra. Márcia Regina Fernandes Boaro Martins

Departamento de Anatomia,

Instituto de Biociencias,

Universidade Estadual Paulista - ULNESP,

Rubiäo gr. s/n

CEP 18618-000

Botucatu, SP - BRASIL

Email: marcia@ib6.unesp.br

Received: 11-07-2005

Accepted: 16-09-2005 